literature was there a manual available containing such a wealth of detailed, carefully documented information.

From the institution of the International Radium Standard Committee Meyer was a very active member, and in 1938, after the death of its president, Lord Rutherford, he became his successor. The Second World War paralysed the activities of the Committee but when three years ago efforts were made again to agree on international regulations for the standardization of radioactive sources, Meyer took a lively interest in them. Letters he wrote to colleagues up to a few days before his death were full of valuable information about previous international negotia. tions, and wise counsel as to how to overcome the present difficulties.

Meyer's activities as director of the Vienna Radium Institute came to an abrupt end in 1938 when the Nazis seized power in Austria; being of Jewish descent, he was dismissed. $\mathrm{He}$ did not leave the country but retired to his house in Upper Austria where he was fortunate enough to live unmolested, thanks to the loyalty of friends and to the courage and devotion of his daughter, who had become a Norwegian by marriage. Several brochures which have since appeared, about the theory of vision and about musical instruments, and a few theoretical contributions to the Mitteilungen (written jointly with his daughter), show that even in retirement his mind was constantly active.

All those who at any time have worked in Meyer's Institute, as his assistants or as guests, remember with deep gratitude his never-failing kindness. It was perhaps the most outstanding feature of his personality; but I refrain from enlarging on it as tribute will be paid to Meyer's friendliness by one who came to know him well in specially difficult circumstances.

F. A. Paneth

I FIRST met Prof. Meyer nearly thirty-seven years ago, when I began work in his Institute. The First World War extended my sojourn in Vienna to nearly six years, and a firm and onduring friendship developed between us. As the only Englishman who has worked in his laboratories, it is perhaps fitting to recall a few personal experiences, for there could be no better revelation of his personal charm and good nature, his warm friendship and his innate kindliness.

Twice in the early months of the War, I was taken into police custody as an 'enemy alien'. On the first occasion Prof. Meyer was at his country home in Bad Ischl, and although I had known him for only a year, he travelled to Vienna as soon as he heard the news, applied for my release, and on the third day he and his 'first assistant', Prof. V. F. Hess, called for me at the Central Police Station and took me home by taxi. On the second occasion he achieved my release on the second day; after that all went well, except that I had no funds and could not for many months communicate directly with my parents. But rather than that I should stagnate in an internment camp, Meyer again intervened. For the rest of the War he supplied me with money on trust and free of interest, the amounts being left to my discretion, and he established intermittent but adequate contact with my parents through the good offices of that greathearted and kindly man of science, Prof. $H$. Kamerlingh Onnes, who devoted much time to work of this kind for others similarly placed to myself.
On all festive occasions throughout the War I never failed to find good things on my work bench from Meyer and his colleagues; at Christmas time Krampus was always there, at Easter the 'Easter hare', and on birthdays an iced cake resplendent with cendles and good wishes. Scientific visitors from abroad could always be assured of friendly discussion and a hearty welcome to the Institute, and I recall how Meyer used to look forward to vacation visits of his old friend Dr. Lise Meitner, a native of Vienna. I remember, too, a visit from Prof. Nernst, and how, with a merry twinkle in his eyes, Meyer said to him : "But before you go you must meet our English prisoner !"

This account would be incomplete without mention of his happy home life with Mrs. Meyer and their son and daughter, all of whom survive; it was one of the high-lights of life in the Institute to be entertained by these charming personalities. In the truest sense, Meyer was an ardent patriot of the old AustriaHungary, and in no wise a hide-bound nationalist. Science to him was international, and he acted accordingly. In his personal relationships he was always sincere; when the situation required it he could be firm, but never unkind. I salute the memory of an outstanding man of science, a true Austrian, and a staunch friend.

ROBERT W. LAWSON

\section{Prof. Battiscombe Gunn, F.B.A.}

BatTiscombe George Gunn, fellow of the Queen's College, Oxford, and professior of Egyptology in the University, died after a long illness on February 27.

Gunn was the son of a London stockbroker and was born in 1883. His father destined him for a business career, and after the completion of his education at Westminster School and Bedale's, he entered the service of a City bank; but although brilliant at figures and entirely competent at his work, he found it so distasteful to his temperament that it was soon abandoned; a second project, that of becoming an engineer, in which his mathematical gyifts would have served him well, was likewise dropped. Gunn's tastes led him into the field of literature and philology, and he early began the study, self-taught, of the language and writing of ancient Egypt. In 1906 he produced a small book, "The Instruction of Ptah-hotep", in which he attempted the translation of one of the oldest and most difficult of literary texts, the Prisse Papyrus in the Bibliothèque Nationale of Paris, a production which, although premature, displays a grasp of the intricacies of the language and a latent talent that was destined to be brilliantly developed later. Gunn had not yet adopted Egyptology as a career, however, and during 1908-11 he was private secretary to Sir Arthur Pinero and afterwards a sub-editor of the Paris Daily Mail.

An opportunity in keeping with his tastes arose when in 1913 he went os assistant to Petrie, who was then excavating in Upper Egypt; and his speçial work was copying the texts discovered and preparing them for publication. In 1914 he joined the Armed Forces; he was eventually invalided out of the Army, and became for some years assistant to Sir Alan Gardiner. It was then that his brilliant powers found full scope. Sir Alan has bimself acknowledged the mutual benefit that arose from this association. In 1924, Gunn published his "Studies in Egyptian Syntax", a work of fundamental import. ance in philology. 
In 1921, Gunn returned to Egypt and took part in the excavations at Amarna, and was afterwards appointed to a post in the Service des Antiquités of the Egyptian Government, when he carried out excavations in the pyramid-field at Sakkara and was an assistant conservator of the Cairo Museum. Thence he pasised to Philadelphia, where he was curator of the Egyptian Department of the Museum (1931-34). The death of Prof. Peet in 1934 rendered the Oxford chair of Egyptology vacant and Gunn was appointed his successor. It was here that he found scope for imparting his vast knowledge to others. This privilege was not only reserved for his own pupils but was freely at the service of his colleagues and friends, especially of young students at the outset of their careers. Gunn never forgot that he was once a beginner himself, and he took infinite pains to give of his best to all who applied to him for help' ; indeed, his letters, of which I have many and have seen many more, are veritable monographs of their respective subjects.

Gunn's published output, in terms of mere numbers, is not large. There are two reasons for this : first, he set himself so high a standard that he never printed any merely interim or provisional work, but always delayed it until he was satisfied that it contained the best he was capable of putting into it ; and secondly, he devoted so much of his time to the service of others that he deprived himself of the benefit of many of his working hours.

Gunn received the honorary degree of M.A. of Oxford, the fellowship of the Queen's College, and was elected in 1934 to the British Academy.

$$
\text { W. R. DAWSON }
$$

Prof. W. P. Wynne, F.R.S.

William Palmer Wynne died on February 16 at Urmiston, near Manchester, in his ninetieth year. The eldest son of a boot manufacturer, Wynne grew up under strict Victorian discipline. At King Edward School, Birmingham, he developed a special interest in chemistry. He was eventually apprenticed to a firm of manufacturing pharmacists, and worked at evening classes, so gaining a free studentship to the Royal College of Science, London, where he graduated with distinction.

In 1886 he became private research assistant to Prof. H. E. Armstrong at the Central Technical College, South Kensington, London, and in 1889 was appointed lecturer. Two years later he succeeded F. R. Japp as assistant professor at the Royal College of Science, serving successively under Profs. T. E. Thorpe and W. Tilden, but still collaborating with Armstrong in his research work.

After two years as professor to the Pharmaceutical Society, Wynne was appointed in 1904 to the Firth chair of chemistry in the University College of Sheffield, which was granted its charter as a full university in the following year. From this time onwards he was increasingly occupied with adminis. trative duties. He was dean of the Faculty of Science continuously during 1911-31 and a member of the Finence Committee of the University for most of that time. Wynne took a leading part in the development of the University; he was particularly interested in student affairs and was largely responsible for the provision of adequate playing fields and their proper equipment. The Chemistry Department flourished under Wynne; but his official duties left him little time for research work. He retired in 1931, at the age of seventy, as emeritus professor, and moved to Cambridge, where his old friend, Sir William Pope, provided him with a laboratory. During the next fifteen years he was able to return to his earlier work on naphthalene and to extend it.

Wynne took his full share in the work of scientific societies, having served as honorary secretary, editor and president (1923-25) of the Chemical Society, and presided over Section B of the British Association at Birmingham in 1913. He was elected to the Royal Society in 1896. During 1938-43 he was a member of the University Grants Committee. He was also a representative of the Sheffield diocese in the National Assembly of the Church of England. He was twice married and had three children, of whom one, a daughter, survives him.

The work which Wynne carried out with Arm. strong during the years 1886-97 was of classical importance in developing the chemistry of naphtha. lene. Its object was to discover the laws of sub. stitution in naphthelene and to provide sure means of determining the orientation of the many substituted naphthalenes that were being discovered. To this end, they first established the existence and the identity of each of the ten possible dichloronaphthalenes. Most of these had already been described by Cleve and other European workers, but Wynne's experiments showed that two of these were non-existent. The sulphonation products of all the dichloronaphthalenes were studied. Displacement of the sulphonyl chloride group gave in each case a trichloronaphthalene, and in this way eight of the fourteen possible trichloronaphthalenes were also identified. Further work led to the isolation and orientation of the remaining six isomerides. The thoroughness with which this work was checked is shown by the fact that, in all, fifty-three independent synthetical preparations were made yielding one or other of the fourteen isomerides.

During these eleven years Armstrong and Wynne made forty-one communications to the Chemical Society on naphthalene chemistry, and much new light was thrown on the naphthylaminedisulphonic acids, the structure of several important members of this group being demonstrated. The collaboration was unfortunately interrupted at the end of 1897, and various circumstances delayed the completion of the work. It is regrettable that the authors did not at that time give full experimental details of their work, which appeared only as short papers in the Proceedings of the Chemical Society. The responsibility for this, however, undoubtedly rested on the senior worker, Armstrong.

In 1941, in collaboration with Miss E. G. Turner, Wynne published a further important paper, describing the products of sulphonating all the tri. chloronaphthalenes, in which the production of fifteen of the twenty-two possible tetrachloronaphthalenes was also recorded, in seven of which the orientation was proved, and in each of the others the position of three of the chlorine atoms was certain. Two years later he described a new tetra. nitronaphthalene. He also published a series of investigations of the sulphonic acids of the chlorotoluenes.

Wynne's work on naphthalene was monumental, and it is fitting that a beautiful collection of some 465 of his specimens should now be preserved in the Research Department of the Dyestuffs Division of Imperial Chemical Industries, Ltd.

G. M. Bennett 